\title{
Islam and Politics: the Case of the Islamic State
}

\section{Mehdi Shokri}

Department of Politics and Department of Philosophy, Free University of Berlin, Fellow of the Konrad-Adenauer-Foundation, Germany

e-mail: Shokri.Phil@gmail.com

\begin{abstract}
:
This paper assesses the fundamental relation between the Islamic-political movements and establishment of the Islamic law (Shari'a). I argue against the critiques of western foreign policy and show that the Islamic State (Caliphate) is both a result of the historical process of the people of a region and the extreme interpretation of the text and Sunna which emphasizes on the traditional Sharia law and the concept of Jihad by fortifying political Islam qua militant Islam. I argue that the Islamic revival aims to a certain political order which threatens the world security and peace. Moreover, I argue that the structural violation of Human Rights is rooted in the traditional concept of Islamic law or Sharia, which obtains its immunity by an illegitimate power. This traditional Islamic law is the inalienable character of authoritarian/totalitarian regimes. This paper is based on the assumption that the extreme ideological/theoretical interpretation implies the empirical objectives of Militant Islamic community with or without any external influential elements. In this sense, we can address the question: how different interpretations and traditions in executing the Islamic Sharia give the social and political grounds a seed for the emergence of violence and terrorism. At the end, this paper ends with a propose which emphasizes on the role of international cooperation to find a resolution and also on the education as a long-term plan to defeat extremism and terrorism.
\end{abstract}

Keywords: Terrorism, Sharia law, Islamic state, political power, education

\section{Introduction}

The rivalries of political powers have always been backed up by certain ideologies and ideas. Some are fair and some are unfair; some are for democracy and some are for dictatorship; some are for human rights, freedom and dignity and some are for enslavement. Muslims are not out of this fighting circle. So when we are talking about extremism, terrorism, Salafism, and Jihadism, we have to consider some points. First, not all Muslims are terrorists. Second, we must know how 'normal' a terrorist, Islamist, Salafist or Jihadist can seem to be. For them, the act of Jihad (war) 
and terror, although is rooted in their belief, seems an entirely rational choice [9]. The Jihad is regarded a pious, selfless, and holy act that mostly promoted by Sunni Islam.

What we today call as an act of terror is any abhorrent act of violence against individuals or states. Yet, terrorism is the widely accepted contemporary political term. Thus, terrorism is an abhorrent act of violence which is used and directed to persuade of particular political aim which cannot be achieved without violence. However, we have to know that the terrorism, unlike its French origin which promotes the positive connotation, became a term associated with the brutality, humanistic crime. It is at this point that we realize no more critiques against the western politics which advocate the idea of the monopoly of the notion of terrorism by western is logically defensible since the notion of terrorism is diverged from the notion of legitimate political act of aggression in both aims and motives [25]. This abhorrent act which was limited to the aim of assassination can be traced back in the early Islam, where it was the practice of political opponents. Yet, today it is turned to the contemporary operational scenarios where terrorism could persist for years and encompass the death of thousands of people [9, p.11]. In this sense, terrorism, Salafism, and Jihadism turned to be a threat to the world security which conducted mostly by non-state actors and non-governmental processes and organizations. For instance, the terrorist attacks on September 11,2001 , redefine terrorism for the West which basically is Jihad for the terrorists.

By a general usage of the term 'terrorism' we can see its connection with the concept of Jihad in which the type of violence can clearly be found in terrorism, Salafism, and Jihadism distinct the phenomenon of Theo-Political violence that it is [25]:

Table 1. Frequency of definitional element in definition of Terrorism [26, pp.5-6].

\begin{tabular}{lc}
\hline Element & Frequency (\%) \\
\hline 1 Violence, force & 83.5 \\
2 Political & 65 \\
3 Fear, terror emphasized & 51 \\
4 Threat & 47 \\
5 (Psychological) effects and (anticipated) reaction & 41.5 \\
6 Victim-target differentiation & 37.5 \\
7 Purposive, planned, systematically organized action & 32 \\
\hline
\end{tabular}

By knowing the subgroups of the concept of terrorism and by distinguishing the concept of terrorism from other forms of crime and irregular warfare, we come to appreciate that terror and Jihad are the identical political concepts.

Both terror and Jihad are:

- ineluctably political in aim and motives;

- violent or the threaten violence;

- design not only to the brutal act of destruction but also to have far-reaching psychological repercussions beyond the immediate victims or targets;

- conducted either by an organization with an identifiable chain of command or by conspiratorial cell instructor whose members are individuals directed by ideological aims.

\section{The Concept of Law and Militant Politics}

The continuance of the emergence of Islamic militant communities and political systems and individual/states terrorist attacks by Islamists, Salafists, and Jihadists are inviting us to ask what makes them violent, illegal and illegitimate? [28].

The first obvious reason is the natural greed for power, but why they act brutally and irrationally? In this sense, we must have a more accurate approach. On the one hand, the link between Sharia (the Islamic Law) and its sources, e.g. the text, and on the other hand, the link 
between the Sharia and the concept of political power would be the clues to answer this question. Furthermore, they can help us in an assessment to see how Muslims understand of the political world.

To the extent that we understand it, Islam has always been a political religion. This is on the contrary to our modern understanding of Christianity and politics. The hierarchical and militant political power has been always an inalienable character of traditional Islamic law. This is due to the nature of some rules which cannot be fulfilled without oppression, and more importantly, is due to the fact that Islamic political power demanding a hierarchical power relation. Though it is not confined to any notion of legality, the holistic picture of traditional Sharia is promoting the totalitarian idea of authoritarian/totalitarian power structure [11, p.15], [21]. It embraces all spectrums of a community. This form of authoritarianism is the core essence of the 'politic Islam' which is known as 'Islamism'. The traditional concept of politics in Islam requires the expansion of Islam to obtain its immunity and fortify its political power. Yet, such expansion, as it is common for all authoritarian/totalitarian power structures, is not possible without invasion and violence [25]. This is where the concept of traditional Islamic expansion inevitably presupposed the idea of Jihad (war) [6, p.3], [14].

\section{Hard Lesson from Religion and Politics}

The traditional Sharia is a despotic radical Islamic law and a political framework which is the vital instrument for the existence of the current forms of radical Islamic power relation and its aim, i.e. an Islamic State. In other words, the Islamic States and, finally, Islamic World are the means and the aims of the traditional Sharia respectively [16]. The reason to that is due to the fact that Sharia is the mixture of strict individual and political laws. Thus, only in a hierarchical World, in which the traditional Sharia presupposed, it can gain power voraciously, rules effectively, and it can be preserved. To that end, Sharia needs two important instruments: militant communities and militant authorities.

The first instrument the traditional Sharia is the militant power-oriented communities. These communities produce Wahabist, Jihadists, Salafists, and Islamists whose main goal is to implement the goals of dar al-Harb (House of War). Dar al-Harb as one of the critical element of traditional 'political Islam' aims at Jihad to make the world an Islamic world [17]. The source of Jihad, basically, emphasizes on those verses of Quran that suggest Jihad (war). Yet, they ignore the historical context in which the verses referring to. The second instrument of the traditional Sharia is the authoritarian/totalitarian power structure with their oppressive legal system. This sort of Sharia law is the result of the interpretation of the verses of Quran along with the tradition, and Hadith the sayings of the early Islamic leaders. In this sense, the traditional Sharia suggests the establishment of a centralized hierarchical political power in which the monopoly of power and law is the absolute and arbitrary rule of a man [11]. Let us call this Islamic political system the Caliphate. In this sense, we can see that Islamism, terrorism, Salafism, and Jihadism is but lack a more precise, concert, and truly rational explanatory definition of the Islam and politics.

Hitherto, we can see that the lack of such truly rational explanatory definition directly helps to form a political regime as the Caliphate which its existence is only possible if it can establish a hierarchical Islamic power relation under the despotic Sharia's umbrella. Where Dar al-Harb, which manages the politics of Jihad, comprises a framework for a systematical foreign policy toward the rest of the world as a battlefield, the traditional Sharia comprises the domestic policy of the Islamic land. The main aim is to try to maintain the hierarchical system under the privilege of one person who is known as Imam or Caliph. Moreover, we can also see that the aim of the traditional Sharia is to centralize an Islamic political power internal homogeneity. However, it is obvious that its illegitimacy leads to the oppression and invasion. Both of these call for a militant power to obtain the immunity of the system - the political Islamic system - and its power holders: the Amirs, Molas, Mollas, Caliphs, and Imams. 
According to the 'political Islam', the traditional Sharia law presupposed the Jihad as its critical essence. Hence, it allows that Wahabist, Jihadists, Salafists, and Islamists kill anybody, disrespect any culture, alight any house, and invade any state that stands against the Islamic poweroriented movements and its aim, that is to overcome the world and to makes it as a global Islamic state [6]. The violation of human rights, inequality between the Muslims and the rest, the privilege in rights of the Muslims over the rest, and the emphasis on the militant expansion of Islam in other states and communities promoted by traditional Sharia law advocates an illegitimate authoritative political system ideology: Islamism and Jihadism [3]. They have all one common point and that is Jihad. Jihad and the hierarchical Islamic power relation are the cornerstones of the global idea of the 'political Islam' qua militant Islam and its domestic policy, respectively. However, from the stands of western politics, the cornerstone of the traditional 'political Islam' is the ground for its illegitimacy, too.

In the last years, the emergence of a terrorist group as the Islamic State (ISIL) is an obvious example that illustrates both the idea of Jihad and the traditional idea of Sharia law under the 'political Islam'. In their idea, Islam and politics are inseparable. Such approach implies that 'not only Islam and Sharia law should rule over the social and political sphere but also it should rule over the private sphere' $[3$, p. 260]. This requires a hierarchical Islamic power relation which presupposed the idea of the 'political Islam'. The 'political Islam' is highly related to the link between the role of the traditional Sharia and Jihad, which aim to shape an Islamic world order [17]. To this aim, the Islamic State e.g. ISIL seeks to destroy everything that is not itself [4]. We cannot argue enough that how such idea is hazardous for a healthy politics. The very nature of ISIL is an Islamic power oriented militant group which role by the 'political Islam'. This core essence is illegitimate. Consequently, ISIL is relentlessly trying to last and expand its militant power. In this sense, today, ISIL is arguably the most dangerous terrorist group that threatens the world security and peace after Al-Qaida [22, part 6].

\section{Politics of the West and the Nature of Sharia Law}

ISIL is catalyzed by the traditional idea of Islamic political power. Since the political aim of the traditional Sharia is to turn the world to an authoritative Islamic state, a centralized oppressive political power seems to be the only way to reach this aim. Its current exercise of power is merely relying on the concept of 'power over' - only if we would use our imagination to be interpreted its violence as power [8], [15]. Its brutal violation of Human Rights and the military oppression which it imposes on the Iraqis, Kurds, and Syrian civilians are the illegitimate acts of aggression [25]. In general, not only ISIL but also the geographical expansions of the traditional rule of Sharia law are the matter of global security and it may be one of the great wars of our time beside communism.

To be specific about this controversial matter, when we are talking about the 'political Islam', Islamism, Salafism, and Jihadism our approach is only political. Here, the aim is not to rely on the theological-philosophical approach to analyze the accountability of a religion or start a discussion on the Islam, but our aim and our discussion is merely political [see also 24, p.30]. Hence, ISIL and political Islam, from the political point of view, are the threats to the world security.

To this extent, the European Union and the United State try to address this matter. Europe as one of the major international actors deploys the traditional European policy which is mostly based on a mere soft power of liberalism and long-term process of cooperation. It has been observed that this method alone cannot fully develop and protect the Human rights observation in international relations, but to some degree, it affects some minor policies of its neighbor states [10]. Europe, at some points, lost the realistic touch on the high priority threats to its security when it comes to setting the scope of its foreign policy. This may be related to its history, the era of colonialism and the wars especially the ones which took place in the twenty-century.

Yet, we can see the daily practice of the traditional Sharia law within the border of European Union (EU) by those who are either immigrant or have the immigration background or 
recently recruited by the Muslim activists. Even in EU, whether it is due to the long tradition of liberalism or the new policies for immigration, the populations with the extreme ideologies are increasing. We can observe that the Islamists and Jihadists form their own groups and impose their rules over their small communities regardless of the law of EU. Moreover, these communities enjoy the liberal idea of the western in which they live since they can/are freely advertising their extreme ideologies and wish to recruit the others for their militant political aims. The most dramatic activities of the militant communities which impose the traditional Sharia can also be seen in England. Today, despite their infamous, we can see that they gather in different spots across the Europe, wearing a long white dress, which is the symbol of acrid Jihad, and advertise their extreme ideologies.

The increase of Islamic extremism in EU, besides of all, creates a backslash. This backslash is in the right-wings groups which are extreme themselves, such as Hooligan and Pegida. In this sense, even to control the activities of the right-wing, one should address the expansion of the traditional Sharia, Islamism, and any related trends.

While ago, this threat brought to light and the challenges that Europe must face has presented by Bruce Bawer in his book While Europe Slept [2]. However, along his argument, one thing is not highlighted and that is the demographical changes across the EU. Maybe, one of the reasons is due to the fact that at his time he could not see a dramatic change in the rate of immigration that mostly caused by the brutal war which is instigated by ISIL in the Middle East. We have to realize that the demographical changes could have a transformative effect. This trend can be vividly seen in England and in France. In England 5.02\% of the population and in France 9.6\% are Muslims. Most of them are Sunni which means that their priority is the 'Political Islam' and Jihad. Between 2000 and 2015 this demographic change also dramatically increased across the EU and after 2015, it can vividly be seen, especially in Germany since a newly-adopted immigration policy [20]. So, we have to ask that how these demographic changes affect on the West?

The increased number of terrorist attacks in EU during the past decade is one of the indicators of the demographic change, the political Islam, and Jihad [29]. So what could be done before the EU would be trapped in the resurrection of the rights-wings or before it would entangle with the irreparable transform? One thing should be appreciated initially, and that is if the liberal values of EU politics revoke the others, then the principles of neutrality subterfuge for a political decision. That means whether EU should decide to act against extremism - in any sense - or stay in the state of neutrality [28]. As the consequence of merely relying on the dialectic method of liberalism, the western democratic norms also would be the first victims of a militant Islamic expansion or other extreme ideologies. Here, we have to ask how long the rational-normative values can be eroded due to the practice of the Sharia law and politics of Jihad which is the ground of local and global terrorism. In other words, Islamism and militant Islamic intolerance are exploiting the western value of tolerance. Emphasizing on the principles of multiculturalism will gradually be ended in losing the roots of Western-Christian civilization. This trend can also be seen in how the Islamists, Salafism and Jihadists ideologies, parallel to each other, have been spreading in Europe in the last couple of decades.

\section{Expansion and Reduction of Extremism}

The bottom-up approach of the expansion of Sharia shows that the first basis of their activities in the West is the Mosques. It is their base-ground in which the seeds of the militant ideology would be expanded. On the one hand, the dramatic and parallel growth of the number of Muslims and Mosques in Europe, in contrary to U.S., and on the other hand, the restless endeavors of the Islamists to turn the old church to the Mosques [13] raise the serious concerns such as:

1. The role of Islamic syndicated around the globe,

2. The graduate expansion of Islamists and Jihadist ideology, 
3. A comparative approach to the role of the traditional Sharia law in the Middle East, Europe, and North America.

From time to time, these concerns are ended in some solutions. Some temporal and some others are permanent. One of the solutions which has been presented for more than a decade ago is 'the war on terror', a term that used initially by the U.S. President, George W. Bush in his 20 September 2001 speech [1, p.19]. The U.S. government of the time saw the modern extremism and terrorism as an international issue which must be addressed immediately. A massive, and consequential, a terrorist onslaught indeed required nothing less than an equally comprehensive and far-reaching response. So, The North Atlantic Treaty Organization (NATO), the military power of the West, got into the war as the result of what the West calls it as the terrorist attacked of 9/11 while the Islamists and extremists call these acrid acts as the act of holy war (or holy Jihad).

Here, there are two major points: one is the partial success of the 'war on terror' was overthrown of some autocrats and dictators of the Middle East, and dismissing some major terrorist groups. If the United States left Afghanistan and Iraq prematurely, jihadists everywhere will be emboldened to take the battle to every place else on the earth [30]. When we look at the history of Islam and traditional Sharia alone, we can see that 'killing the political opponent' and terror was the main or almost only way of their politics. Even at the very beginning of their history, the era of four caliphs including Abu Bakr, Umar, Uthman, and Ali, one after another was the victims of their own tradition of terror attack. It was the same tradition of terror attack that forced Ali's dynasty to immigrate to Iran and shape Shi'a as a cult against Sunni. To be sure that those who follow the school of Sayyid Qutb and the similar ideology of anti-western politics know very little, if nothing, about the theo-political problem of the traditional Sharia and its history.

In this sense, the concept of terrorism must be respected as a serious and literal term of military and political threats of Islamism, Salafism, and Jihadism. The other point is about the concept of 'war on terror.' It seems that there has been two misunderstanding in the 'war on terror'. First, we have to distinguish between the temporal solutions for the problem of traditional law, terrorism, and politic of Jihad and the permanent one. Second, we have to look deeper into this matter. One of the appropriate approaches to the concept of 'war on terror' is the one from the geopolitical perspective [5]. Talking about the 'war on terror' is more complex and more controversial that it seems. From the geopolitical approach, 'war on terror' in the Middle East is not as the same as 'war on terror' in the United State. The range of potential and actual adversaries against the West thus expanded beyond Osama bin Laden, Al-Qaida's leader, and the other minor groups. It also expanded beyond the basic threats of ISIL in Iraq and in Syria. Moreover, the concept of 'war on terror' cannot be reduced to the military act of the West. In other words, this war can take place in every sphere: in education, in religion, in the process of legislation, etc.

\section{The Birth of New Methods}

Do we learn from the past? It may be interesting to know that it is only 'the people' that are the real guardians of their values. Yet, it is more important to understand that the seed of western democracy cannot fertile in the Middle-Eastern, at least not that soon. Democracy needs a free land and 'mind' to be cultivated and the infertile ground of the Middle East is not yet ready. The Middle East politics is paved with the soil of hatred. It is the place that forgets nothing and forgives nobody. The shadow of their immortal God always speaks to them, lead them. Thus, we might first ask what we should do. To make the Middle East ready is to try to engage the local people in the international program of 'war on terror' [23].

Indeed, the United States' and NATO's missions in the Middle East, Africa, and East Europe has gained unquestionable results by their humanitarian missions, overthrowing the authoritarian/totalitarian power, and crippling the active terrorist groups. Indeed, military actions win the most in military and geographic dimensions. This is one of the reasons that president Obama calls the unilaterally ordered air strikes of August 2014 against ISIL as a 'necessary' action. 
However, the military aspect of 'war on terror' lacks some vital elements to affect the culturalpolitical aspect of a state; and even sometimes causes that the militant Islamists react more harshly. More importantly, though failure to take action against terrorists such as ISIL will result in irreversible consequences, relying merely on the military aspect of 'war on terror' causes that the regular folks felt a sense of war against their land and against themselves. Their reaction would be offensive and skeptical about any political changes in their countries.

So what should be done more? If we want to see a real progress to defeat the terrorism, extremism, Salafism, and Jihadism, we have to consider two reforms. One should take place in the western foreign policy and the other one should take place in both the western and the Middle Eastern domestic policies. In fact, the western foreign policy should be a homogenous mixture of European and North American ones.

Moreover, such foreign policy must be flexible and sensitive. It must be flexible to know that what the West appreciate as the liberal-democratic norms may not be appreciated or protected or even work in Iraq or in any Middle-Eastern countries. It also must be sensitive to take any necessary measure to defend the Western values against the extremism, Islamism, Salafism, and Jihadism. Moreover, the mixture of the methods means that the 'war on terror' should also be defined as the relentless long-term efforts on cultural, educational, economic, and ideological reforms. These reforms must help to redefine the Sharia law from the radical traditional form to a new moderate and peaceful one. In other words, unlike its thousand-years traditional path, Islam should be secularized in which a new concept of Sharia should revoke the traditional one [12]. To do that, the nature of Islam as a political religion must turn to be Islam as a religion for the individuals. This reform should take place, especially in the Middle-East, where the concept of the traditional Sharia implies a justified legal system. The new interpretation of Sharia refutes the concept of Jihad and promotes the concept of peace in the Muslims communities [6]. In this way, the threat against the world security would be decreed. Here, let us elaborate on these points that have been just said and pose the final proposal.

\section{ISIL and Its Fall}

Preliminary, we know that the ideological ground of ISIL which are the Islamism, Salafism, Jihadism are the most tangible and dangerous threat to the world security and peace. So, how we can practice critique on their threat? There are two dimensions to address the problem of the 'Political Islam' as an extreme militant ideology [17]: locally and globally, and in both ways, it should be addressed fundamentally and pragmatically. So let us elaborate on these points. First, the concern is with the global peace and security in respect to the expansion of ISIL and its threat to the world. Hence, a coordinated international solution can partially address this problem. To fight back ISIL effectively, not only calls for 'the legitimate act of aggression', e.g. military concept of 'war on terror', which it seems inevitable, but also a great deal must be done on the other concepts of this legitimate war: the moderate interpretation of Islamic texts, the refuted notion of Jihad, and a new form of Sharia law. This is the considerable point that General David Petraeus described in The U.S. Army - Marine Corps Counterinsurgency Field Manual as "clear, hold and build" [19, ch.9].

The first dimension to address the extremists and terrorist threat to the global world security and peace is to institutionalize bilateral security governance. The universal unanimity in the international policies must be made against any oppressive, fascistic, militant and extreme ideologies [see also 23]. In both ways, the United Nation (UN) has a legitimate capacity to grow their security governance function to address these global issues. The United Nation's presupposed resolution should center on the observation of Human Rights, security of each region, and peace around the world. Yet, its governance program should shape the education and culture of the developing countries effectively. The North Atlantic Treaty Organization (NATO) and Organization for Security and Co-operation in Europe (OSCE) also have the capacity to address the threats that posed by extremism and terrorism, particularly the threat that pose by ISIL [18]. Specifically, NATO and OSCE can address such challenge by developing the global 'security 
governance'. It is in this way that they can address the Islamism fundamentally. The bilateral character does not only emphasize on the co-operation between Europe and North America, since in global concept, western regard as one actor. In fact, the western security governance, on the one hand, must have a compact co-operation with the regional security organization of other regions, and on the other hand, a high sense of unanimity with the United Nations.

The second dimension to address the problem of the Islamism, Salafism, Jihadism, and terrorism that threaten the world security and peace is a long-term reform. This would be the permanent concept of 'war on terror'. This dimension can only take place if the first dimension can be successful. However, in details, the second dimension can be broken down as follows:

1. The first step is to reform the traditional militant Sharia. This reform is to democratize and to moderate the Islamic laws. This can be done in two ways: first, it starts in our home, in the West. The first plan is to revise the western educational system and the second is to act cooperatively with the moderate Muslims globally [24]. The change is to act progressively and actively, not passively. This means that the aim of this act is revision and building. To do so, there should be the educational-cultural programs, in the Western academic structure [24], to educate a moderate Muslim generation. They should learn how to secularize Islam. That is to interpret the text and Sunna (tradition) in a way that Islam be the source of faith of individuals and, also by some countries, a national culture [12]. This would be the vital and permanent approach to counter the wave of Islamism, extremism and Jihadism. In this way, western countries won't become the host of fanatic ideologies, but on the contrary, they will become a 'source' of a moderate ideology of Islam by which they can educate their Muslims residents and then Muslims in the Middle East and Africa. This approach is one of the fundamental ways to stop spreading Islamism, Salafism, and Jihadism across the western countries - securing homeland - and consequently address the problem concerning the global security. Moreover, the reform is also included the political decision on the question concern "who can teach the Islam in the West?". The clerks and Mollas who has an affiliation with militant Islamic powers and ideologies or who promote the idea of the 'Political Islam' are relentlessly spreading Islamism and Jihadism [17]. Thus, they must be sent back to their countries and as substitution, their place will be offered to the moderate educated Muslims who would promote the peaceful Islam. Hitherto, the seats of moderate Islamic theology in the departments of philosophy still are empty. So, in this sense, there is a wider political concept which is missing.

2. The second step is to expand the programs of transformation from the 'political Islam' to the secularized Islam in the Middle East. One way is to teach the new interpretation of the sources to form a Sharia which emphasizes on the moderate concept of Islamic thoughts. In this sense, the revision of Islamic ideologies in other states, such as the Middle Eastern countries, is possible only with a long-term transnational corporation [25]. The aim, here, is to engage the people of each region to reach their political-consciousness $[24,25]$. In the Middle East, the moderate Muslims would be the effective player to reform the 'Political Islam' and refute the concepts of Islamism, Salafism, and Jihadism. While the West has a supporting role, it is ultimately the responsibility of the moderate Muslims to lead this effort [7, p.17]. They can form a new notion of religion that makes the society face the new world with its modern and compatible Islamic identity, not with the barbaric and antique heritage [12]. Thus, traditional Sharia as a poweroriented set of law which requires a militant community and political power aim to 'Islamisize' the world, should be highly avoided, stopped for functioning and above of all should be reformed by the new form of Sharia which will be relying on the new moderate interpretation of the source of laws. Therefore, the Islamic heritage as an individualized religion will be saved for those who would believe in Islam as a peaceful, individualistic, and non-political religion, and on the contrary, the Islamic political power, the idea of 'Political Islam', Islamism, and Jihad would be the absurd terms and will be refuted. 
3. The third step is to establish the academies to make sure that the military and police are well schooled in the theory and practice. They should learn how to deal with the terrorism, Islamism, Salafism, and Jihadism. What are the theoretical grounds of these acts? What are the strategies of the counterterrorism? The Combating Terrorism Center at The U.S. Academy in West Point, New York could be a good sample of this plan. Yet, we need such academy in all over the world, especially in the West, were the target of these extremists' groups are.

To sum up, it is to be sure that the 'war on terror' is the appropriate way to address the threat that posed by the extremists, Islamists, and Jihadists. Yet, we have to fully appreciate, on the one hand, what the 'war on terror' is? And how we can defeat the extreme trend of militant political Islam in a long-term.

\section{Acknowledgement}

I wish to thank Dr. h. c. Berthold Gees for all of his help and kindness to prepare the earlier drafts.

\section{References}

1. Badcock, D., and Marks Darren, C. War, Human Dignity and Nation Building: Theological Perspectives on Canada's Role in Afghanistan. Cambridge Scholars, Newcastle upon Tyne, 2010.

2. Bawer, B. While Europe Slept: How Radical Islam Is Destroying the West from within. Doubleday, New York, 2006.

3. Berman, Sh. Islamism, Revolution, and Civil Society. Perspectives on Politics, Cambridge Journals 1(2), 2003, pp. 252-272.

4. Eikmeier, D. C. Qutbism: An Ideology of Islamic Fascism. Parameters, Spring, 2003, pp.85-98.

5. Graham, S. Cities, War, and Terrorism: Towards an Urban Geopolitics. Blackwell, Malden, MA, 2004.

6. Gregory, M. D. Religion of Peace? Islam's War Against the World. World Ahead Publishing, Inc., Los Angeles, 2006.

7. Hajjar, Sami G. Avoiding Holy War: Ensuring That the War on Terrorism is Not Perceived as a War on Islam. In. Defeating Terrorism: Strategic Issues Analysis. John Martin (ed.). US Army War College, Strategic Studies Institute, Carlisle, Pa., 2002.

8. Haugaard, M. and Ryan., K. (eds.) Political Power: The Development of The Field. Barbara Budrich Publishers, Opladen, 2012.

9. Hoffman, B. Inside Terrorism. Columbia University Press, New York, 1998.

10. Ivanova, R. Europe's Soft Power: Limits and Possibilities. Harvard University Press, Cambridge, Mass., 2008.

11. June, D. L. Terrorism and Homeland Security: Perspectives, Thoughts, and Opinions. Taylor \& Francis: Boca Raton, 2011.

12. Karpat, Kemal H. The Politicization of Islam: Reconstructing Identity, State, Faith, and Community in the Late Ottoman State. Oxford University Press, Oxford, 2001.

13. Kern, S. Muslims Converting Empty European Churches into Mosques. Gatestone Institute, International Policy Council, January 2012. Available via http://www.gatestoneinstitute.org/2761/converting-churches-into-mosques

14. Kepel, G. Jihad: The Trail of Political Islam. Harvard University Press, Cambridge, Mass., 2002.

15. Lukes, S. Power: A Radical View. Palgrave Macmillan, Basingstoke, 2005.

16. Marco, R. Obama's terror strategy is failing: U.S. must heed lessons of 9/11. Marco Rubio, January 2015. Available via http://www.rubio.senate.gov/public/index.cfm/newsarticles?ID=ba16f641-8129-4675-a893-e6ae09b51626

17. Muthuswamy, Moorthy S. Defeating Political Islam: The New Cold War. Prometheus Books, New York, 2009. 
18. Peterson, J. W. NATO and Terrorism: Organizational Expansion and Mission Transformation. Continuum, New York, 2011.

19. Petraeus, D. The U.S. Army/Marine Corps Counterinsurgency Field Manual. The University of Chicago Press, Chicago, 2007.

20. Pew Research Centers. The Future of the Global Muslim Population. Pew Research Centers Religion Public Life Project RSS, January 2011. Web. 15. Feb. 2016. Available via https://www.pewforum.org/2011/01/27/the-future-of-the-global-muslim-population/

21. Rehman, J. Islamic State Practices, International Law and the Threat from Terrorism: A Critique of the 'clash of Civilizations' in the New World Order. Hart Publishing, Oxford, 2005.

22. Rajan, V. G. J. Al Qaeda's Global Crisis: The Islamic State, Takfir, and the Genocide of Muslims. Routledge: New York, 2015.

23. Saul, B. Terrorism. Hart Publishing, Oxford, 2012.

24. Shokri, M. Rhetoric Tradition and Democracy: Isocrates' Role in Ancient Greek Political Idea. Start Point of Western Political Philosophy. Studia Humana 4.3, 2015, pp.14-36.

25. Shokri, M. Legitimacy and Theory of Political Consciousness: Evaluating Political Act of Aggression. Journal of Political Sciences \& Public Affairs 4.1, 2016, pp.1-8.

26. Schmidt, A. P., and Jongman, A. J., et al. Political Terrorism: A New Guide to Actors, Authors, Concepts, Data Bases, Theories, and Literature. Transaction Books, New Brunswick, 1988.

27. Schmitt, C. The Concept of Political. University of Chicago: Chicago, 1996.

28. Terror Attacks and Arrests in Western Europe. The Economist. The Economist Newspaper, 16 Nov. 2015. Web. 14 Feb. 2016.

29. Vertigans, S., Donncha, M., and Sutton, W. P. Militant Islam: A Sociology of Characteristics, Causes, and Consequences. Routledge, London, 2009.

30. Yew, L. K. The United States, Iraq, and the War on Terror. Foreign Affairs, December 2015. Retrieved February 13, 2016, Available via https://www.foreignaffairs.com/articles/iraq/2007-0101/united-states-iraq-and-war-terror. 